\section{P94 CYTOCHROME P450 OXIDOREDUCTASE ENZYME DEFICIENCY: A CASE REPORT}

${ }^{1}$ Illker Tolga Özgen, 'Esra Kutlu, ${ }^{1}$ Hatice Nursoy*, ${ }^{1}$ Yaşar Cesur, ${ }^{3}$ Gözde Yeşil. 'Bezmilaem Vakif University Hospital Department of Pediatric Endocrinology, Istanbul, Turkey; ${ }^{2}$ Bezmilaem Vakif University Hospital Department of Pediatrics, istanbul, Turkey; ${ }^{3}$ Bezmilaem Vakif University Hospital Department of Medical Genetics, İstanbul, Turkey

\subsection{6/archdischild-2019-epa.449}

Background Cytochrome P450 Oxidoreductase (POR) deficiency is one of the rare forms of adrenal insufficiency. It causes suspicious genitalia in boys. The disorder in steroid synthesis carries the symptoms of both 21-hydroxylase and 17-20-lyase deficiency. Cortisol deficiency is not frequent, but the stress response is impaired.

Case An 8-month-old male patient was admitted to our hospital with vomiting for 15 days. Hyponatremia and hyperkalemia were detected in the first laboratory tests of the patient and he was hospitalized for further investigation. In the background: The patient was born at term by caesarean section. His birth weight was 3600 grams, developmental stages were normal and he had no hospitalization before. Family history; the parents were healthy and they were unrelated. Physical examination; Height: $65 \mathrm{~cm}(-2,23$ SDS; $<3 \mathrm{p})$, weight: $6.6 \mathrm{~kg}$ (-3.01 SDS; <3p), head circumference: $43 \mathrm{~cm}$ (-1.53 SDS; 310p). Blood pressure: $100 / 62 \mathrm{mmHg}$, pulse: $130 / \mathrm{min}$, respiration rate was $35 / \mathrm{min}$. The general condition was moderate, the skin turgor was decreased and the skin was pale. His systemic examinations were normal, externally in male view but he had hypospadias and bilateral undescended testes. The laboratory tests are given in table 1 . Abdominal ultrasound was

\begin{tabular}{|c|c|c|c|}
\hline $\mathrm{Hb}(\mathrm{g} / \mathrm{dl})$ & 11,6 & ACTH (pg/mL) & $133(<46)$ \\
\hline WBC $(/ \mu \mathrm{l})$ & 13200 & cortizol (ug/dL) & $2.5(0.54-15.9)$ \\
\hline PLT $(/ \mu l)$ & 333000 & $\begin{array}{l}\text { 17-OH progesterone (ng/ } \\
\mathrm{mL} \text { ) }\end{array}$ & $208(0.03-1.48)$ \\
\hline Glucose (mg/dl) & 97 & androstenedione (ng/ml) & $0.67(0.03-0.15)$ \\
\hline ALT (U/L) & $25(8.7-39)$ & 11-Deoxycortisol (ng/mL) & $0.18(1.1-2.76)$ \\
\hline Urea (mg/dl) & $57(5-23)$ & DHEA-S & 20.50 \\
\hline creatinine(mg/dl) & $0.57(0.34-0.54)$ & Renin (ulU/mL) & $>5500$ \\
\hline sodium (mmol/l) & $121(139-146)$ & Aldosterone (ng/dL) & $14.8(3.7-43.2)$ \\
\hline potassium (mmol/l) & $6.56(4.1-5.3)$ & Total testosterone $(\mathrm{ng} / \mathrm{mL})$ & $0.24(0-4.92)$ \\
\hline $\begin{array}{l}\text { Dihydrotestosterone } \\
(\mathrm{pg} / \mathrm{mL})\end{array}$ & $1778.3(<50)$ & & \\
\hline chlor (mmol/l) & 91 & blood gases $\mathrm{pH}$ & 7.48 \\
\hline urine $\mathrm{pH}$ & 7 & bood gases pco2 $(\mathrm{mmHg})$ & 18.8 \\
\hline urine density & 10 & bood gases hco3 $(\mathrm{mmol} / \mathrm{L})$ & 14 \\
\hline urine ketone & negative & $\mathrm{BE}(\mathrm{mmol} / \mathrm{L})$ & $-7,6$ \\
\hline
\end{tabular}

\begin{tabular}{llll} 
Abstract P94 Table 2 & & & \\
\hline & 0 minute & 30 minutes & 60 minutes \\
\hline ACTH $(\mathrm{pg} / \mathrm{mL})$ & 120,3 & & \\
cortizol (ug/dL) & 3,7 & 4,1 & 4,5 \\
17-OH progesterone (ng/mL) & 305 & 369 & \\
androstenedione (ng/ml) & 1,32 & 1,39 & \\
11-Deoxycortisol (ng/mL) & 0,31 & 0,44 & \\
DHEA-S & 27,30 & 38,8 & \\
\hline
\end{tabular}

normal. Scrotal ultrasound showed bilateral testes in inguinal canal. Adrenal insufficiency was considered in the preliminary diagnosis. Performed ACTH stimulation test's results are in table 2 .

Results The patient is considered to have POR deficiency and his genetic research is in progress. Hydrocortisone $15 \mathrm{mg} / \mathrm{m} 2 /$ day and fludrocortisone $0.1 \mathrm{mg} /$ day were prescribed. We presented this case for discussing POR deficiency as a cause of rare adrenal insufficiency.

\section{P95 THE UNDECLARED NEW TYPE OF PONTOCEREBELLAR HYPOPLASIA}

${ }^{1}$ Olga Rybalko, 'Larisa Fedorova, ${ }^{1}$ Nikolay Kaladze, ${ }^{1}$ Galina Dosikova, ${ }^{3}$ Natalia Afanasieva, ${ }^{4}$ Demidenko Elena*. 'V I Vernadsky Crimean Federal University, Simferopol, Russian Federation; ${ }^{2}$ St Petersburg State Pediatric Medical University, St Petersburg, Russian Federation; ${ }^{3}$ Crimean Perinatal Center, Simferopol, Russian Federation; ${ }^{4} \mathrm{~V}$ I Vernadsky Crimean Federal University Medical Academy named after S I Georgievsky, Simferopol, Russian Federation

\subsection{6/archdischild-2019-epa.450}

Background Pontocerebellar hypoplasia (PCH) refers to a group of severe neurodegenerative disorders affecting growth and function of the brainstem and cerebellum, resulting in serious neurological consequences or psychomotor delay. Different types are classified according to the clinical picture and the spectrum of pathologic changes.

Method Clinical, genetic, molecular, encephalographic, radiological, pathological and survival data were gathered.

Results The patient report presents the medical history of a pontocerebellar hypoplasia $(\mathrm{PCH})$ child, which unrepresented in previous case histories. Our patient has a heterozygote mutation in 8 exon gene TSEN54 and in 1 exon in gene EXOSC3. It is important to note that such a mutation in TSEN54, however, in different exons is presented in $\mathrm{PCH}$ type $2 \mathrm{~A}, \mathrm{PCH}$ type 4 and $\mathrm{PCH}$ type 5 and a mutation in gene EXOSC3 is demonstrated in PCH1B. We compared all known PCH types (19 PCH types) and tried to find correlations between this child's features and those associated with the other one. This case tries to resolve the diagnostic issues related to the combination of features of these different types simultaneously in one child. Clinical features include seizures, feeding and swallowing disorders, strabismus, kyphoscoliosis, poor balance and coordination, mental retardation, severe speech impairment, hypotonia. Our patient had some phenotype peculiarities, such as: brachycephalia, protruding brow arcs, preauricular excrescence, medial eyebrow flare, hypoplasia of the lower face, large nose, eyelids ptosis. The morphological changes of this case were microgyria, pontocerebellar hypoplasia, and corpus colosum hypoplasia. Moreover, an MRI confirmed TH4 rachischisis, and an ultrasound revealed thymomegaly and septal defects. An EEG demonstrated slow flashes with high-amplitude. In the frontal leads we can see epileptic discharges and periods of disorganization of cortical rhythm. EMG results were normal. Blood test showed no abnormalities. Uncontrolled seizures made the child's condition unstable and he needed palliative care.

Conclusion Therefore, our investigation continues to determine whether the child has a pontocerebellar hypoplasia $(\mathrm{PCH})$ with undeclared molecular karyotype or has a combination of $\mathrm{PCH}$ type $2 \mathrm{~A}, \mathrm{PCH}$ type 4 and $\mathrm{PCH}$ type 5. 